\title{
Promoting Fave Hotel's Rungkut Meeting Rooms and Rooms Using a Marketing Booklet
}

\author{
Alexandra Ricci Pradnya Paramita \\ English Department, Faculty of Languages and Literature, Petra Christian University, Siwalankerto 121 - \\ 131, Surabaya 60236, Indonesia \\ E-mail: alexandraricci09@gmail.com
}

\begin{abstract}
Fave Hotel Rungkut is a 3 - star hotel, located in J1. Kaliraya Rungkut No. 23 - 25. Fave Hotel Rungkut has 175 total rooms with 169 standar rooms and 6 suite rooms. They also offer 4 medium and 2 large meeting rooms. Their main competitors are Cleo Business Hotel, Zest Hotel Jemursari, and Amaris Magarejo. The main problem that Fave Hotel Rungkut is facing is the decline of upselling rooms and meeting rooms in September - November 2018. To solve the problem, I made a marketing booklet to help sales team sell the products of Fave Hotel Rungkut. A marketing booklet is made in English and Indonesia in order to make their local and foreign customers understand. This marketing booklet will be useful and helpful for sales and marketing team to promote or show their products to their target market.
\end{abstract}

Keywords: Promotion, Hotel, Marketing Booklet

\section{INTRODUCTION}

Fave Hotel Rungkut is a 3 - star hotel located in east Surabaya, Raya Kalirungkut No. 23 -25, and was established in 2015. It is run by Archipelago group and owned by Mr. Setiawan. Fave Hotel Rungkut has been running for two years as of now, with total rooms 175 from $1^{\text {st }}$ floor up to $12^{\text {th }}$ floors. They have 2 kinds of rooms, standard and suite rooms. They offer six types of meeting rooms, starting from medium, large, and ballroom. Medium meeting rooms, known as Bromo meeting room, comes in many sizes and large meeting room, known as Semeru meeting room, has 2 sizes. Not only accommodating bedrooms and meeting rooms, Fave Hotel Rungkut also provides facilities such as Lime restaurant, swimming pool, and Wab spa for guests. The customers of Fave Hotel Rungkut are government, companies, travel agencies, school or university, and business people. Fave Hotel Rungkut has three competitors which are Cleo Business Hotel, Zest Jemursari and Amaris Magarejo. Compare to their competitors, Fave Hotel Rungkus has more spacious parking lot, two different swimming pools, and large meeting rooms.

Within three months of my internship in Fave Hotel Rungkut, I found a problem that related to Business Communication Final Project. The problem that Fave Hotel Rungkt facing is that meeting rooms and rooms are not selling very well. There were declined in September 2018 until November 2018. From the data of occupancy, it showed that the occupancy of meeting rooms and rooms were declined up to $72 \%$ for meeting rooms and $68 \%$ for rooms from the maximum $80 \%$.

Thus, I decided to pick the problem of promoting the occupancy Fave Hotel Rungkut's meeting rooms and rooms as my Business Communication Final Project because those products are the main products of this hotel that can help the sales achieve their target. Therefore, I will make a marketing booklet of Fave Hotel Rungkut. The reason why I choose a marketing booklet is because it will be useful and helpful for sales and marketing team to promote or show their products to their target market. Besides, there are some benefits that Fave Hotel Rungkut gets 
by having a marketing booklet. First, marketing booklet help sales \& marketing sell and explain their products and services to customers. Customers will have clear image by looking at the booklet because booklet contains more information which provides some photos or image. Next, the other departments can use this booklet as product knowledge especially, a new staff or an intern.

To create and finish completely, I use some theories to make a marketing booklet. The theories are about brand \& branding, promotion, types of marketing tool, marketing booklet, unique selling points, and color. These theories are from book and online source to understand about the definition, purposes, features used in making a marketing booklet.

The first theory is about brand and branding. Wheeler (2018, p.2) defines "brand as competition creates infinite choices, companies look for ways to connect with customers, become irreplaceable, and create lifelong relationships. A strong brand stands out in densely crowded market place". Based on explanation above, brand is the intangible that makes people love, trust and believe product of company. Brand is not only about logo, tagline, or trade mark but, it is more than that which can affect customer's thought about that company. Also, he defines branding as "a disciplined process used to build awareness, attract new customers, and extend customer loyalty. Positioning a brand to be irreplaceable requires a daily desire to be the best". It can be concluded that branding is the process to get customer attraction to buy product and to build brand awareness. Branding is the way to promote company's brand to costumers so they can believe and buy the products that company offers.

After explaining about brand and branding, the second theory is about promotion. The definition of promotion is "the mix of promotional elements a firm uses to communicate with potential customers about its products or services", according to Cuellar (2013, p.4). I conclude that promotion is a way to introduce your products or services to customers. The promotion is also the combination of brand and branding. Promotion uses brand to introduce company toward customers then, promotion makes a way to promote the products and services that company sell. After that, there are 3 objectives of promotion based on Shimp (2007, p. 446). First, Company uses promotion to make consumer to use brand. As what I have explained before, promotion is to introduce a brand of company to their target market. The function is to make their target market to choose this brand. Second, it encourages company's sales force to sell it aggressively. The sales are expected to get more customers to choose this company's products or services because the sales have been helped to introduce products and services through promotion. Third, Company wants to encourage customers use this brand than competitor. In hope that after knowing the brand, customers will chose this brand to fulfill their desire.

Next, it is about types of marketing tools. There are many ways to deliver and promote a company, products, or services to customers. According to Mullin (2010, p.30), the types of promotion or marketing tools can be divided into four different tools. First, advertising is paidfor space and time in broadcast, print media (brochure, newspaper, magazine, and other printed media) and the new media (TV, website, interactive TV and SMS). Second, publicity (PR) will deliver or carry information and opinion about products or services. PR is the one who introduce products, services, or events in company to customers. Third, direct marketing is one person presents to customers which they can respond directly. Direct marketing is also known as personal selling by face to face. The last one, sales promotion is salespeople who are incentives and offer products or services to customer using selling technique such as asking questions, listening customers' needs and other persuasive efforts. The job of sales promotion is to sell the products and services to get customers. Sales promotion usually people who meet the customers directly. Among all these promotional tools, I will be using advertising tool which is 
print media as my business communication final project. Printing media that I will use is marketing booklet.

After choosing a marketing booklet as business communication final project, the next theory that I need is a marketing booklet theory. According to Oxford Dictionaries, Booklet is a small thin book with cover that contains information. Then, I also took the definition of marketing according to Oxford Dictionaries, "The activity of selling products of company". From that explanation above, I can conclude that marketing booklet is a small book that provides more information about company's products or services used to sell it to customers. Marketing booklet also has several benefits according to Craig (2018) and Stephenson (2007, p.375). First, booklet is easy to distribute to target audience or customers. One way to simply distribute booklet is by displaying them in strategic places. For a hotel, strategic places can be in a lobby hotel whereas people will gather in that place before they go to room, meeting room, or restaurants. Another places, they can display it in their booth of exhibition. Second, booklet has lot of information. I can put information that customer need to know about the company in marketing booklet because booklet has more spaces which is enough to put some pictures and map of a company's location. The function of booklet is to give information about products or services' company which include some photos. Also, booklet has specific target market. Third, if I made the designed well, I hope that it can grab attention and entertain potential customers. Designed well makes customers has a clear image about this products. If they read through the pages and are interested, they will contact the hotel for further information. Fourth, the function of a booklet can be as a promotional kit but, booklet also can be given out as a gift. Booklet can be filled in the goody bag with other promotional kit such as note pad, glass, mouse pad, flyers, and others.

In addition, the elements of a marketing booklet are divided into two elements: it is basic and important elements. In basic elements, there are some features in making marketing booklet. The pages of booklet are 16-24 pages. The size of booklet is small enough to fit in business envelope. The size is 3.5 inches x 8.5 inches or $9 \mathrm{~cm}$ x $21 \mathrm{~cm}$. Moreover, A booklet usually has a plain of color and minimal graphics or designs based on Bly (2009, p. 37 - 38). While in important elements there are five elements according to Honor (2012), they are basic content, organization, how-to guides, branding and graphics. First of all, basic content is a part which contains information about products or services that company offers. Basic content help customers or readers to get enough information about the products and services. Second, organization is a part which contains table of contents. In this part, the function of table of contents is to make the booklet more organized. This part helps customers to get the information that they want to know. Third, how- to guide is a part when giving information about company in order to make customers believe that company's products / services. By using the USP of company make the customers believe that their products are better than competitors. Fourth, branding is a part which logo should be put in each page of booklet. Company also needs to use the same fonts, colors, and tone to make it consistent. Consistency will reflect on company. Fifth, graphics is a part which photos or images use high quality. Images in booklet also represent company. High quality will affect customers or the readers to read and have image about company. Besides the basic elements, there are some requirements to follow in order to make a marketing booklet. First, a company should use selective wording. Selective wording is needed to avoid wordiness. Too many words will influence to customers' willingness not to read the booklet through the pages. That is why in marketing booklet should use selective wordings. Second, a company should make table of contents in marketing booklet. The function is to make the booklet organized. It also helps customers to get information quickly. Third, a company should give a brief introduction. It is usually known as company overview which tells the readers about the company, products, and services that they offer. Fourth, a company put the content itself. The content in this part starts from the product, services, and facilities that company offers to customers. This is information which company wants to sell to 
the readers. Fifth, contact information should be included in a booklet. Contact information is needed in order get in touch with this hotel. Contact information consists of address, e-mail, phone number, fax number, and website. The five steps that I have explained above are the steps that I will follow for my marketing booklet project. This steps will help me to make marketing booklet looks professionals.

Moving to next theory, I use the theory of unique selling points to get USP of a company. According to Stone (2009), "USP, is a crucial element in defining competitive advantage. It means that USP is something that makes the products or services different from others. It is like what a company has but, the competitors do not have it or the products are better than competitors. He said that to get the USP, company should identify what makes the products or services different from competitors and identify what the benefits that customers get when using this products from this company. The function of knowing the USP is to give advantage to customers.

The last theory that I used is color theory. According to Funk (2009, p.67), "Color is strongly linked to brands. Typically companies have a primary color. The primary color is often paired with a secondary color". Based on explanation above, it can be concluded that color can represent companies. Company usually has one color that dominates their brand than the second color.

\section{METHOD}

To create my Business Communication Final Project, there are some steps that I did. First, I met and asked permission to make a marketing booklet to hotel manager, Santi Manurung, and sales \& marketing manager, Melani Novitasari. I also explained to them why I changed promotional video into a marketing booklet. After explaining the reasons, they finally accepted my project and allowed to make it. After that, I started collecting information about rooms, meeting rooms and got some data like customers' satisfaction. Next, I made a proposal containing the problem, the solution, and the cost of hiring the designer and photographer in order to make the booklet they looked interested when knowing the concept that I told them. Then, we did negotiation and we agreed with the number of payment. The next things, I made a letter of agreement on the other week and asked the hotel manager or sales \& marketing manager to sign the letter as our agreement. As the result, I got sales \& marketing manager signature.

Next step is the step to create a marketing booklet. After my proposal got accepted by the company including the cost for making the marketing booklet, I collected more information related to meeting rooms and rooms by interviewing the sales \& marketing staff. As the result, I got information such as the total rooms and meeting rooms, the meeting room capacity and its facilities. To get the unique selling points of this hotel, I made a questionnaire for 30 guests. There were several steps that I had done in order to get USP. First, I asked permission front office manager to put the questionnaire in front office then I gave him my questionnaire to be an example. On the same day, I consulted it with human resource department to get his approval. Human resource manager and hotel managers allowed me to give questionnaire to customers under one condition: it was the food and beverage department who could distribute the questionnaire because I was not an intern anymore. Hence, human resource manager helped me to get permission from food \& beverage manager. After these steps were done, I put my questionnaire and was waiting the texts from human resource department to get my questionnaire back.

In addition, the questionnaires were distributed for 30 guests who stayed in the hotel. The respondents were 40 guests but, there are only 30 guests who answer all the questions. Besides that, I also had interviewed with 6 customers who cancel and 6 customers who use meeting room in this hotel. I got the data of customers who cancel and use meeting room from the sales 
$\&$ marketing staff. After interviewing customers and distributing questionnaires done, I started discussing the layout and the concept with the designer about the design that put in marketing booklet. To make the concept, I interviewed human resource manager to get the idea in making concept. The next step, I started to make a draft for the concept of marketing booklet based on the theory from Tara Honor (2012), Tips for Better sales booklet. The following step is to take photo that I needed to put in marketing booklet. After done with taking photo, collecting information, getting the USP, I continue consulting the products and services that I put in a marketing booklet. The last one, I consulted to my advisor about the wordings and revision of this booklet. After that, I did finalizing.

\section{FINDINGS AND DISCUSSION}

As aforementioned, I decided to make a marketing booklet for Business Communication Final Project for Fave Hotel Rungkut. I chose a marketing booklet than other marketing tools because marketing booklet has more complete information. It aims to give customers better understanding about the products and services that hotel provides by giving some pictures in each page and giving detail information. After considering the target market of Fave Hotel Rungkut and interviewing 12 customers and sales \& marketing staff, a marketing booklet is suitable to solve the problem that Fave Hotel Rungkut is facing. The marketing booklet is made in the form of English and Indonesian only because their guests are not only from Indonesia but, they also have guests from outside Indonesia. Fave Hotel Rungkut's marketing booklet uses minimalist concept for the design. The reason is because minimalist has simple design but it looks elegant. Also, the overall colors of the booklet are white and magenta because of the brand colors this hotel. The size is $21 \mathrm{~cm}$ x $21 \mathrm{~cm}$ in order to be read clearly. The paper uses art paper $210 \mathrm{gr}$ to prevent it from folds and I gave doff lamination in front and back cover so that it looks more elegant. This booklet has 28 pages starting from front cover within back cover. Furthermore, I will explain the 7 components of Fave Hotel Rungkut marketing booklet; they are about us, products, facilities \& services, important places, special offer, map, contact us.

First, it is about company overview. As what the theory I mentioned in chapter 2 according to honor (2012), a marketing booklet should have company overview. The words "company overview" I changed it into "about us "because it sounds more communicative toward customers or readers. I also use two languages which are English and Indonesia because the most of their customers are Indonesian people but, they also have guests from other countries and it still follows the rules of this hotel which uses English language for sales tool. About us in marketing booklet consists of what Fave Hotel Rungkut is and why people should choose Fave Hotel Rungkut as their accommodation. I also emphasize the USP of this hotel by mentioning affordable and beneficial. The picture that I used is Fave Hotel Rungkut from outside to make customers familiar with its building. In the left, there is a brand logo of Fave Hotel Rungkut to emphasize that this company overview is about Fave Hotel Rungkut.

Second, it is the products description. The first product is rooms. This component discusses about total room, room size, bed type, facilities, and benefit. This content will make the readers or customers have better understandings regarding two types of rooms. They also can see the difference between suite room and standard room through this content because there is a benefit in each type of room. Not only knowing the difference between suite and standard, they can ensure whether this hotel is suitable for their needs or not by giving information such as the total room, room size, and facilities. I also underline room types to emphasize that this page talks about room products. All room types use 4 selected pictures that can show the difference between suite and standard room. The other product is meeting rooms. In meeting room products, the information consists of size, capacity, and facilities of meeting room so that customers know which meeting room they want to use and fit their need. Each meeting room has two pictures in left page with big size in order to make customers understand the different of 
the capacity and the set-up of the meeting room. There is also a note below the pictures in order to make customers understand the meaning of set - up in classroom, theater, u shape, and banquet.

The following component is facilities. In facilities and services, I gave a picture of a cup of coffee in one page. I put this picture as the transition from meeting room to facilities and services. Moreover, I increase the fonts of facilities and services to make readers know that this topic explains about facilities. In these facilities, I started with Lime restaurant. I made a picture in the right bigger than others to make the readers know that this is Lime restaurant of Fave Hotel Rungkut. Brief information about Lime restaurant is also added in the below in order to give readers information about their speciality. On page 20, it talks about swimming pool and Wab spa. I put a picture of swimming pool and Wab Spa to show that this hotel provide these facilities to customers. I also put a computer in order to be known by customers or the readers about these facilities. Aside from it, I mentioned the other facilities on the next page such as free Wi-fi, parking space, extra bed, laundry, and airport transport. I only use white background without adding pictures because it contains different facilities and white background makes it look minimalist. Also, the previous facilities have already had some pictures.

Fourth, it is important places. Important places consists places that most of guests like to visit like Transmart Rungkut and Sier Industries. Beside it, the places that I mention are the reason why customers chose this hotel as their accommodation. This hotel is close to companies, university, and workplace and this makes the location of Fave Hotel Rungkut as one of this hotel's USP. The location is strategic for those who want to go to Sier industries, Surabaya University or banks and restaurants.

Fifth, it is about special offer. Special offer contains information about a special discount for room that hotel offers. I put the image of apple store and play store to show the readers or customers that Archipelago app can be downloaded through that application. Either the readers use apple or android, they can get a special discount by downloading that app. Besides, a syombol " $\mathrm{A}$ " in the top represents a picture of its app in apple store and Google play so the readers will not be confused when they want to download this app in Apple store or Google play.

Sixth, it is map and contact information components. First, I made the map in one page so that the map can be read clearly. In the map, the location of Fave Hotel Rungkut is marked with its logo. The function of the map is to make the location can be found easily. Besides, I also bold the important places in map so that readers know how far those important places from this hotel. In map, there is arrow to show way to go to Juanda airport. This map helps readers find the location of the hotel and important places by looking at the map. Second, I put contact information in different page from map. The function is to make customers or readers to get in touch with Fave Hotel Rungkut. I only use English in contact information because it will save the space from many words. By using English only, both Indonesian and foreign guests understand the meaning.

The last one, it is back cover of Fave Hotel Rungkut. For the back color, I only use magenta color which is the same with front cover to make it consistent. I also gave doff lamination in back cover so the color will look strong and elegant. The function also makes the art paper thicker even all the paper use art paper 210 gr. In the left below, I put the logo of Fave Hotel Rungkut again so the readers can see that this is Fave Hotel Rungkut's marketing booklet from front and back cover. 


\section{CONCLUSION}

For Business Communication Final Project, I decided to make a marketing booklet for Fave Hotel Rungkut. Actually, the first tool that I wanted to make was promotional video but, I changed it into a marketing booklet due to the target market. I came up with a marketing booklet because the upselling of occupancy of meeting room and room in Fave Hotel Rungkut were low in September - November 2018. It can be seen through the data that I got. The decline was $90 \%$ - $72 \%$ for meeting room and $74 \%-64 \%$ for room from the maximum $80 \%$. Thus, creating a marketing booklet for Fave Hotel Rungkut can help the sales \& marketing promote their special products which are meeting rooms and rooms.

Hence, the usage of marketing booklet for this hotel will be used for sales \& marketing team. They use it for supporting their explanation to customers about the products and services that hotel offers. Besides, marketing booklet has more complete information that includes some pictures, detail information, map, and contact information. Then, customers will have better understandings and clear image about Fave Hotel Rungkut. Moreover, the benefit of having marketing booklet can also be used for other departments in Fave Hotel Rungkut such as front office, food \& beverage, and accounting who usually send their staff to be a representative in exhibition. Throughout this booklet, they can learn the product knowledge of this hotel. The last one, my suggestion for those who take internship in next semester, students need to choose company which relates to their future dream job.

\section{REFFERENCES}

Bly, R. (2009). 88 Money - Making Writing Job. Naperville: Sourcebooks.

Craig. (2018). 5 Benefits of Using Booklets and Brochures for Your Marketing. Retrieved from https://www.instantprint.co.uk/printspiration/marketing-with-print/5-benefits-of-usingbooklets-and-brochures-for-your-marketing.

Cuellar, S. (2013). Marketing Module 8: Promotion. Ithaca: Cornel University.

David Funk, A. M. (2009). Concious Branding. New York: Business Expert Press.

Honor, T. (2015, March 7). Tips for Better Sales Booklets. Retrieved from www.business2community.com/marketing/tips-for-better-sales-booklets-0274390

Hornby, A. S. (2010). Oxford Advanced Learner's Dictionary. Oxford: Oxford University Press

Shimp, T. A. (2009). Integrated Marketing Communications in Advertising and Promotion. Boston: Cengage Learning.

Stephenson, J. (2007). Ultimate Small Business Marketing Guide: 1500 Great Marketing Tricks That Will Drive Your Business through The Roof. Irvine: Entrepreneur Press.

Stone, P. (2001). Make Marketing Work for You: Boost Your Profits with Proven Marketing Techniques. Oxford: How To Books Ltd.

Wheeler, A. (2018). Designing Brand Identity fifth edition. Hoboken: John Wiley \& Sons, Inc. 